\title{
THE SHAPE AND CONTENT OF POST-APARTHEID AFRICAN LAW: ACADEMIC SCHOLARS IN CONVERSATION ${ }^{*}$
}

\author{
Dial Dayana Ndima \\ BJuris LLB LLM LLD \\ Senior Lecturer, College of Law \\ University of South Africa (UNISA)
}

\begin{abstract}
SUMMARY
The interim Constitution of 1994 unleashed a heated debate about the role of African customary law as part of the South African legal system. The point of departure was the extent to which the Western-oriented liberal Bill of Rights could be applied without sacrificing the system's normative values. During the constitutional negotiations it was unsuccessfully proposed that African customary law be insulated from the application of the Constitution in order to preserve the legal system's indigenous character. The debate turned on two academic positions, one of which was a pessimistic liberal view that sought to reject African customary law, whilst the other was against the imposition of the Western value system on African traditions. Some academics asserted that mutual influence of both systems is possible, since progressive development of African law is necessary.
\end{abstract}

\section{INTRODUCTION}

The attainment of freedom in 1994 created the opportunity for the African value system to contribute to the development of South African law. The challenge was how to forge the version of African law envisioned by the Constitution through ridding the system of the colonial/apartheid influences and distortions, exhuming and resurrecting its indigenous normative values before infusing them with the spirit of the Bill of Rights. The objective was to transform African law into a substantive component of South African law that was on a par with the common law of Roman-Dutch-English origin.

The powder keg that triggered the war of words between human rights activists and traditionalists was the simultaneous recognition of human rights and African culture in the 1993 interim Constitution". The traditionalists saw

This article is based on the edited version of Chapter 1 of Ndima Re-imagining and Reinterpreting African Jurisprudence under the South African Constitution (unpublished doctoral thesis, UNISA 2013).

Himonga and Bosch "The Application of African Customary Law under the Constitution of South Africa: Problems Solved or Just Beginning?" 2000117 SALJ 306310. 
human rights as Western-oriented and posing a threat of turning the Constitution's equality provisions into a present-day repugnancy clause for undermining African law, whilst the human rights activists saw African law as a patriarchal stumbling block to the attainment of women's and children's rights. $^{2}$

These two groups metamorphosed into spirited lobbies that were prepared to politically annihilate each other in their quest to designate the version of African law envisioned by the Constitution. The threat posed by the human rights activists' gender equality crusade drove the traditionalists to launch a double-pronged campaign to discredit the interim Constitution as a Western document foreign to African culture, ${ }^{3}$ and to seek African law's exemption from the impending threat of the constitutional review process that increasingly seemed inevitable. ${ }^{4}$ Alternatively, the traditionalists vowed to secure a guarantee that African law would be applied in the courts of the democratic South Africa if the traditional leaders and their constituencies were to participate in the then impending new dispensation.

Eventually the undertaking to entrench the application of African law in the final Constitution was secured by the inclusion of articles XI-XIII to the Thirty-Four Constitutional Principles in Schedule 4 of the interim Constitution which contained principles that had been negotiated to guide the Constitutional Court during the certification proceedings that would precede its approval. ${ }^{5}$ The academic debate currently under review is a natural response to the conundrum created by the Constitution's recognition of African law, subject to its constraints. ${ }^{6}$

\section{THE APPLICATION OF AFRICAN LAW IN ITS INDIGENOUS SETTING}

It is appropriate at this juncture to view the evidence of indigenous eyewitnesses to the application of African culture on how they experienced it in their own lives before listening to the versions appropriated to it by later scholars who interpreted it according to their acquired perspectives. It is only in this manner that one can independently assess the veracity of the various versions of African law proposed by the participating disputants.

Contemporary academic scholars are broadly divided according to their perspectives on the nature of the African value system and its role in South Africa's constitutional democracy. ${ }^{7}$ Hence their insights must be measured

Himonga and Bosch 2000117 SALJ 310.

Lehnert "The Role of the Courts in the Conflict between African Customary Law and Human Rights" 200521 SAJHR 241.

4 Bennett "Re-introducing Customary Law to the South African Legal System" 2009 LVII(1) The American Journal of Comparative Law 1.

Himonga and Bosch 2000117 SALJ 312.

See s 211(3) of the Constitution of the Republic of South Africa, 1996

See Lehnert 200521 SAJHR 241; Bennett Customary Law in South Africa (2004) 1; Himonga and Bosch 2000117 SALJ 306; Herbst and Du Plessis "Customary Law v Common Law Marriages: A Hybrid Approach in South Africa" 2008 12(1) EJC L 1; Grant "Human Rights, Cultural Diversity and Customary Law in South Africa" 200650 (1) JAL 13 ; Nhlapo "Human Rights - The African Perspective" 1995 6(1) ALR 38; Pieterse "Killing it Softly: Customary Law in the New Constitutional Order" 2000 De Jure 3536. 
against the views of their antecedents such as Mqhayi, ${ }^{8}$ Soga, ${ }^{9}$ Setiloane, ${ }^{10}$ Solilo $^{11}$ and Jolobe, ${ }^{12}$ all of whom became Christian priests after being brought up in the African tradition that was based on the indigenous values of group solidarity and communal interest at the dawn of the $20^{\text {th }}$ century before they were seriously eroded by colonial morality.

These works refer to an era characterized by lack of self-interest, where access to resources was directed by shared entitlement and common belonging to collective households. They describe a world view that constrained the power of decision-makers to the exigencies of common interest, which throws some light on the values ingrained on the indigenous African culture before it was affected and infected by alien distortive influences.

Mqhayi's contribution demonstrates the metaphysical environment in which elders, men, women, and the youths interacted in their efforts to resolve social issues, ${ }^{13}$ and shows how the adverse effects of patriarchy were neutralized and manipulated by the system's flexibility in its application to protect individuals within the communal life of pre-colonial Africans. ${ }^{14}$

Solilo considers the interaction between religion and culture in influencing law and politics in the creation of an order in which the decisions of the living were ultimately sanctioned by the living dead and the gods, ${ }^{15}$ whose intervention explains how a society without formal government structures such as the police, courts and public service controlled crime by influencing the consciences of individuals.

Setiloane's African concept of God shows how the indigenous religion fostered the observance of the custom of initiation to produce men and women of integrity who kept order and promoted prosperity among communities. $^{16}$

Soga contrasts African culture with Western civilisation by decrying the substitution of a dysfunctional European value system for the tried and tested African one. ${ }^{17}$ The author resents the distortion of African culture based on the usurpation of the African decision-making powers by colonial officials who adjudicated on customs about which they knew very little. ${ }^{18}$

According to Jolobe the advent of technologies, such as the use of draught animals and vehicles, could relieve women of the chores that were

\footnotetext{
Mqhayi Ityala Lamawele (author's translation - The Twins' Case) (1914).

Soga Intlalo KaXhosa (author's translation - The Culture of the Xhosa People) (1935).

Setiloane The Image of God Among the Sotho-Tswana (1976) 36-55.

Solilo "Izinto Zekomkhulu LamaXhosa" (author's translation - "Xhosa Royal Symbols") in Bennie Imibengo (1935) 219.

12 Jolobe "Umsebenzi Wabafazi Kwisizwe Esintsundu" (author's translation - "The Role of Women in African Society") in Bennie Imibengo (1935) 224.

Mqhayi Ityala Lamawele 51-52.

Ibid.

Solilo in Bennie Imibengo 219-222.

Setiloane The Image of God Among the Sotho-Tswana 36-43.

Soga Intlalo KaXhosa 94-100.

Soga Intlalo KaXhosa 94.
} 
traditionally reserved for them, e.g. drawing water and cultivating crops. ${ }^{19}$

\section{THE APPLICATION OF AFRICAN LAW UNDER COLONIAL AND APARTHEID LEGISLATION}

A different set of scholars are those who view African law, not from the tradition itself, but from its application by colonial and apartheid authorities. Among them are Kerr, ${ }^{20}$ Bekker, ${ }^{21}$ Bennett, ${ }^{22}$ Koyana and Mqeke, ${ }^{23}$ whose starting point was the examination of the application of colonial and apartheid legislation in the courts. The difference between these scholars and those discussed in the previous paragraphs is that their African law was the official version which did not necessarily coincide with the indigenous one that was current in community practice. This view of African law, conceived from the extra-cultural world view of the colonial and apartheid officials became distorted because legislation and court decisions, not the tradition, were its major sources. With the application of judicial precedent, the dominant official version of African law became stunted, petrified and tended to lag behind the actual social developments. ${ }^{24}$

\section{THE VIEW THAT THE CONSTITUTION PERPETUATES THE INFERIOR STATUS OF AFRICAN LAW}

Thomas and Tladi are disillusioned by the Constitution's endeavour to force a reconciliation of the irreconcilable principles of African law and international human-rights law. ${ }^{25}$ They view the constriction of African law through the Bill of Rights as a recantation of the repugnancy dispensation. Thomas and Tladi see the imposition of Western notions of human rights on African law in the Bill of Rights, as subjecting African culture to the same opprobrium that existed under apartheid. For that reason they perceive the

19 Jolobe in Bennie Imibengo (1935) 224-226.

20 Kerr "Inheritance in Customary Law under the Interim Constitution and under the present Constitution" 1998115 SALJ 262.

21 Bekker Seymour's Customary Law in Southern Africa (1989).

22 Bennett Customary Law in South Africa 357 writes: "Under customary law, the death of the family head leaves his wife and daughters dependent on the goodwill of a man who might be a comparative stranger, for the heir is not necessarily the widow's natural son. Moreover in a typically self-serving interpretation of the patriarchal tradition, an heir may claim that the widow cannot be owner of property she brought in to the marriage. He may then claim that he is entitled to such property as successor to his father's estate. As notional owner, the heir can dispose of it for his own purposes, paying only lip service to the duty to consult the widow. She must put up with this situation, because, if she leaves, she loses any right to support." Unfortunately Bennett uses the lack of enforcement of customary-law rules under colonial/apartheid rule as the weakness of customary law itself. In fact the heir he is describing is in violation of his customary-law obligations.

23 Koyana and Mqeke "Traditional Authority Courts" in Bekker, Rautenbach and Goolam (eds) Introduction to Legal Pluralism in South Africa (2006) 131.

24 Bhe v Mgistrate Khayelitsha; Shibi v Sithole; Human Rights Commission v President of Republic of South Africa 2005 (1) SA 580 (CC).

25 Thomas and Tladi "Legal Pluralism or a New Repugnancy Clause" 1999 XXXII CILSA 354 361. 
recognition of African law as nothing more than palliative, since the same censorship based on Eurocentric morality and public policy in the past, is now perpetuated under the Bill of Rights. ${ }^{26}$ Such sentiments are echoed by Koyana and Mqeke, ${ }^{27}$ for whom the retention of a repugnancy clause, as entrenched in section 1(1) of the Law of Evidence Amendment Act, 45 of $1988,{ }^{28}$ and its improved version in section 211(3) of the Constitution represents the resilience of the old order. ${ }^{29}$

For Koyana and Mqeke the Constitution has not improved the status of African law, since old-order legislation, such as section 1(1) of the Law of Evidence Amendment Act, which subjects the interpretation of the African law to common-law values, remains intact. This is borne out by the fact that the repugnancy clause of the past coexists with the new Bill of Rights, both of which treat African culture with the same level of disdain. Consequently, Koyana and Mqeke see no difference between the customary law of the old order and its post-1994 manifestation. ${ }^{30}$ This is echoed by Bennett who also decries the retention of the repugnancy proviso in the new order, and suggests that it is due only to some legislative oversight that it is still on the statute book, as it has no role in the present era. He reckons that African law today needs only to be consistent with the Bill of Rights. ${ }^{31}$ As far as Bennett is concerned, the repugnancy clause merely serves as a hoary reminder of colonial rule. ${ }^{32}$

\section{THE VIEW THAT AFRICAN VALUES ARE INCONSISTENT WITH THE SOUTH AFRICAN CONSTITUTION}

Keveey, ${ }^{33}$ English, ${ }^{34}$ and Kroeze ${ }^{35}$ see African law and its value system as

26 Ibid. See also Juma "From 'Repugnancy to Bill of Rights': African Customary Law and Human Rights in Lesotho and South Africa" 2007 21(1) Speculum Juris 8890.

27 Koyana and Mqeke in Bekker, Rautenbach and Goolam (eds) Introduction to Legal Pluralism in South Africa 143, write: "In addition, the repugnancy clause remains in place as ever before, whereas on attainment of independence it was abandoned in many countries. It was considered unfitting to the dignity of the indigenous laws of the people of those countries to suggest the repugnancy existed. In South Africa, the repugnancy clause is still applied. It is presently contained section 1(1) of the Law of Evidence Amendment Act. Its application is further secured by section 211(3) of the Constitution, which directs the courts to apply customary law, subject to the Constitution and to existing legislation, and thus subject to the repugnancy clause in the Law of Evidence Amendment Act. The problem with the repugnancy clause is that it imposes Western values on customary law."

28 Act 45 of 1988 .

29 Juma 2007 21(1) Speculum Juris 88 states: "[A]frican law subsists on the fringes of juridical activism, its authority and content articulated within the narrow margins of utility provided by pluralism. But even within this narrow space, African law still has to contend with 'morality' standards pegged on a human-rights culture underwritten by regimes of international law."

30 Koyana and Mqeke in Bekker, Rautenbach and Goolam (eds) Introduction to Legal Pluralism in South Africa 143.

31 Bennett 2009 LVII(1) The American Journal of Comparative Law 2.

32 lbid.

33 Keveey "Ubuntu versus the Core Values of South African Constitution" 2009 43(2) Journal of Juridical Science 19.

34 English "Ubuntu: The Quest for an Indigenous Jurisprudence" 199612 SAJH 641.

35 Kroeze "Doing Things with Values II: The Case of Ubuntu" 20002 Stell LR 26. 
irreconcilable with the South African Constitution and international human rights. ${ }^{36}$

Keveey, in particular, denies that ubuntu is in consonance with the values of South Africa's new constitutional order because, as the basis of African law, it sustains the deep-seated patriarchal hierarchy which entrenched inequality in African society. Keveey finds the judgments of the Constitutional Court in $S v$ Makwanyane $e^{37}$ and Bhe $v$ The Magistrate Khayelitsha ${ }^{38}$ contradictory in that whilst the former stresses harmony between ubuntu and the Constitution, ${ }^{39}$ the latter paints a gloomy picture of patriarchy in African law that derives its potency from ubuntu which, in turn, reserved for women a position of perpetual minority. Despite his acknowledgement of the consistency among judges and scholars who confirm the synergy between ubuntu and the core values of the Constitution, Keveey questions this consonance and concludes that both African values and their belief system trump and erode the core values of the Constitution. ${ }^{40}$

Similarly, English views the campaign for the jurisprudence of ubuntu as a rather desperate effort to find a legitimate African imprimatur for indigenizing the set of civil liberties listed in the Bill of Rights. He is, however, not convinced that any of these attempts has succeeded in establishing a guiding constitutional norm for deciding the side on which ubuntu would prevail when the interests of the individual and those of the community are in balance. ${ }^{41}$ For English, the high levels of rationality and justice in ancient societies in Africa, that Justice Sachs acclaims in various judgments, should not mean that ubuntu, without further evidence of its efficacy, can dictate the invalidation of validly enacted legislation. ${ }^{42}$

English also regrets that all that ubuntu can contribute in the postapartheid enthusiasm for indigenization, is to provide an opportunity for reconciliation when, in fact, what is called for is revenge. ${ }^{43}$ English insists that since constitutional adjudication is about conflict, the resurrection of ubuntu from desuetude in an effort to promote "a specifically ethnic South African jurisprudence is bound to fail". ${ }^{44}$ Meanwhile Kroeze does not see what the matter is with the ubuntu hype as its conceptual values are already sufficiently captured in the existing Western value system. ${ }^{45}$ In doing so she overlooks the importance of the emergence of an indigenous African counterpart of the Western value system.

\footnotetext{
Keveey 2009 43(2) Journal of Juridical Science 19; English 199612 SAJH 641 and Kroeze 20002 Stell LR 26

1995 (3) SA 391 (CC).

2005 (1) SA 580 (CC).

Keveey 2009 43(2) Journal of Juridical Science 19.

Keveey 2009 43(2) Journal of Juridical Science 21 and 53.

English 199612 SAJH 642.

English 199612 SAJH 645.

English "1996 12 SAJH 646.

English 199612 SAJH 648.

45 Kroeze 20002 Stell LR 26.
} 


\section{THE VIEW THAT THERE IS A SYNERGY BETWEEN THE AFRICAN VALUE SYSTEM AND THE SOUTH AFRICAN CONSTITUTION}

In their various ways scholars such Mahao, ${ }^{46}$ Dlamini, ${ }^{47}$ Nhlapo, ${ }^{48}$ Juma $^{49}$ Pieterse ${ }^{50}$ and Lehnert ${ }^{51}$ support the view that the African value system, underpinned by the jurisprudence of ubuntu, is compatible with the South African Constitution. Individually and collectively they exhibit a demonstrable harmony between the indigenous norms that are warehoused in the concept of ubuntu, and the Bill of Rights. As a result their collective contribution points to a belief in the ability of African jurisprudence to advance the constitutional project to transform South Africa's legal and political environment.

In support of this position Mahao challenges the impression created by the detractors of African culture that African jurisprudence is conservative and is inconsistent with the South African Constitution. ${ }^{52}$ In amplification, he conflates African jurisprudence with ubuntu/botho which he regards as the very root of African humanism and the epitome of homocentricity in African philosophy. ${ }^{53}$

Mahao further challenges African scholars to consider African jurisprudence as a valuable source of insights for reimagining ways for resurrecting the continent's failed development project, and for reviving the hopes for democracy, human rights, and social cohesion currently under threat from neo-liberal globalization. ${ }^{54}$ Such conditions demand a distillation of ubuntu/botho as a normative value system that could assist in reinventing contemporary state institutions in the image of Africa's indigenous institutions. Mahao proceeds to call upon African scholars to direct their attention towards African jurisprudence as a strategy by which to restore democratic accountability, indivisible human dignity and social cohesion, which traditionally nurtured a symbiotic synergy between the limits of royal power and the extent of popular enfranchisement.

In its unique way, indigenous governance bound royal power to popular approval through mass participation in all decisions that were taken during a free expression of ideas. Mahao defines human dignity in the African context as comprising physical, spiritual, cultural and material wellness, which was the nucleus of humaneness in the pursuit of indigenous statecraft. ${ }^{55}$ The preponderance of these qualities in the African judicial tradition paved the way for the development of restorative justice.

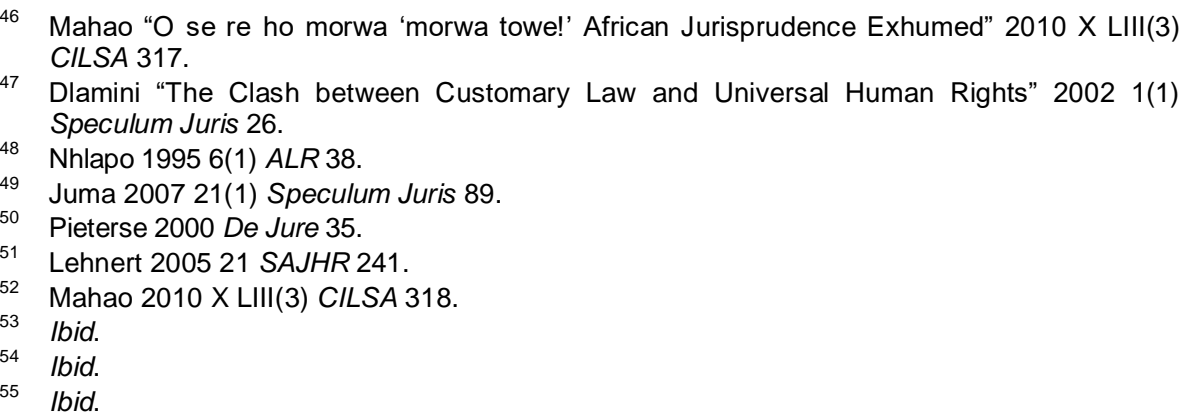


Mahao illustrates how King Moshoeshoe of Lesotho prevailed against calls for the imposition of the death penalty on convicted murderers driven to cannibalism by material deprivation unleashed by the difaqane/imfecane ${ }^{56}$ catastrophe. The strength of the ethic of restoration in African jurisprudence, in which humanism meant treating the worst criminal mercifully, formed the basis for the king's insistence on the value of forgiveness in the face of national outrage against the criminals. ${ }^{57}$ This reconciliatory attitude provides an historical response to English who remains unconvinced of the wisdom of choosing forgiveness in the face of calls for revenge. ${ }^{58}$

Mahao goes back in history to illustrate ubuntu's notable record in the distribution of social justice in traditional societies. He joins Soga in blaming the decay of African culture and its value system on colonization which concentrated on recrafting African culture in the image of the corruptible Western civilisation. Mahao links this form of cultural imperialism to the grave coexistence of civil rights with material wretchedness, and blames it on the absence of ubuntulbotho in modern democracies. ${ }^{59}$

In earlier times Soga had similarly blamed the downfall of traditional governance and its institutions on the imposition of Western institutions whose lawyers and magistrates (including judges) usurped the judicial functions of traditional authorities by making decisions on indigenous institutions about which they never had sufficient understanding, such as lobolo, traditional marriages, initiation, rituals, royalty and succession. ${ }^{60}$ For Soga, the imposition of the Western-style of governance, which substituted money fines and the imposition of prisons terms for cattle as forms of punishment, served to divert the wealth generated by litigation from its traditional social beneficiaries, the people, to lawyers who became rich, but had no corresponding social responsibility towards the poor. ${ }^{61}$ Under the indigenous system wrongdoers were fined cattle which were then distributed to the impoverished victims of injustice. $^{62}$

Both Soga and Mahao reminisce about the days when the traditional institutions handled their own affairs with dignity, and deplore the loss of respect for the African tradition, and the demise of its structures which has seen them replaced by inadequate Western institutions. ${ }^{63}$ These scholars insist that African traditional institutions were successful in socio-economic redistribution which was the source of the deep respect and esteem that the traditional governments enjoyed in the pre-colonial period. As already pointed out Mahao refers to the time of the imfecane/difaqane ${ }^{64}$ brutalities, to

56 Mahao 2010 X LIII(3) CILSA 319 explains difaqane as the "[s]ocial upheavals caused by wars among the African communities of southern Africa by the end of the second decade of the nineteenth century. These led to the emergence and consolidation of new nations in the region."

57 Mahao 2010 X LIII(3) CILSA 330-331.

58 Mahao 2010 X LIII(3) CILSA 318-320.

59 Mahao 2010 X LIII(3) CILSA 326.

Mqhayi Ityala Lamawele 94.

61 Ibid.

Mqhayi Ityala Lamawele 94-95.

Mqhayi Ityala Lamawele 94 and 330.

64 These terms refer to the huge social, political, economic and humanitarian upheavals sparked by the formation of the Zulu Kingdom in the early $19^{\text {th }}$ century that shook the 
illustrate the genius of home-grown African humanism which generated hope for scores of people under conditions of utter traumatization that would have dwarfed the capacity of today's self-serving Western institutions. ${ }^{65}$

Accordingly, the African tradition imposed the responsibility on everyone so that no one could be an island in life. Mutual dependence was a humanrights value which instilled in the minds of all Africans that umuntu ngumuntu ngabantu/motho ke motho ka batho (author's translation - a person is a person because of others) ${ }^{66}$ This sense of community compelled everyone to treat other people as he/she would like to be treated. The kinship networks that this interrelationship generated extended beyond relatives, to include strangers, and indeed enemies. ${ }^{67}$ This ethic of humanness has become the ethos of South Africa's constitutional jurisprudence, engendered by the philosophy of ubuntu.

Joining this conversation Dlamini asserts that, properly understood, the concept of ubuntulbotho is in fact synonymous with human rights; ${ }^{69}$ and proceeds to demonstrate judicial support for the impossibility of the notion that African law is in conflict with human rights. He refers to the Constitutional Court judgment in $S v$ Makwanyane, where Madala $\mathrm{J}$ held that the Constitution owes its human-rights attributes to its permeation by the spirit of $u$ buntu (that is the source of African values). ${ }^{70}$

Adding his voice to this debate Pieterse believes that ubuntu is so important in African jurisprudence that no text can be complete without it. ${ }^{71}$ $\mathrm{He}$ attributes the significance of this concept to various academic ${ }^{72}$ and judicial $^{73}$ efforts to lend legitimacy to South Africa's post-apartheid

foundations of all institutions in the southern and central African regions. Mahao $2010 \mathrm{X}$ LIII(3) CILSA 319 erroneously fixes the turmoil in the first quarter of the $18^{\text {th }}$ century. In fact this was the $19^{\text {th }}$ century as the height of defaqane/imfecane was during the decade 1820 1830.

65 Mahao 2010 X LIII(3) CILSA 319.

66 Ibid.

67 Ibid. See also Biko "Some African Cultural Concepts" in Coetzee and Roux (eds) Philosophy from Africa - A Text with Readings (1998) 26. At 28 he writes: "Poverty was a foreign concept ... In almost all instances there was help between individuals, tribe and tribe, chief and chief, etc, even in spite of war."

68 See S v Makwanyane 1995 (3) SA 391 (CC) and Port Elizabeth Municipality v Various Occupiers 2005 (1) SA 217 (CC); Dikoko v Mokhatla 2006 (6) SA 235 (CC).

69 Dlamini 20021 1(1) Speculum Juris 46.

70 Dlamini 2002 1(1) Speculum Juris 44 referring to $S v$ Makwanyane 1995 (3) SA 391 (CC) par 238-245.

71 Pieterse "'Traditional' African Jurisprudence" in Roederer and Moellendorf (eds) Jurisprudence (2004) 438441.

72 Some of the academics who expressed themselves on the concept of ubuntu are Van Niekerk "A Common Law for Southern Africa? Roman Law or Indigenous African Law?" 199831 CILSA 159 168-169; Mokgoro "Ubuntu and the Law in South Africa" 31 October 1997 Paper delivered at the first colloquium Constitution and Law held at Potchefstroom at http://www.puk.ac.za lawyer/1998-1/mokgoro-ubuntu.html 1; English 199612 SAJH 641; Kroeze "Doing Things with Values: The Role of Constitutional Values in Constitutional Interpretation" 200112 Stell LR 265; Lenta "Just Gaming? The Case for Postmodernism in South African Legal Theory" 200717 SAJH R 173; Cockrell "Rainbow Jurisprudence" 199612 SAJHR 1.

73 Among the earliest court judgments involving ubuntu are S v Makwanyane 1995 (3) SA 391 (CC); AZAPO v President of RSA 1996 (4) SA 671 (CC) and Hoffman $v$ South African Airways 2001 (1) SA 1 (CC). 
jurisprudence which needs to forge common ground between the Constitution and indigenous values.

Nhlapo endorses these sentiments by saying that the future of South African law lies in the integration of the culture of the majority of the country's inhabitants ${ }^{74}$ as the basis for the transformation of the national value system. Like Mahao, Nhlapo fingers the Western-oriented international human-rights movement for recreating the world in the image of the West. Consequently Nhlapo cautions that such universalization of Western norms threatens to swamp African culture once and for all. ${ }^{75}$ According to Nhlapo, these inequalities in the administration of human rights have alienated many Africans who perceive them as suggesting that theirs was a delinquent culture that needed to be fixed by a "superior one".

For Nhlapo this is reminiscent of the approach of European missionaries of some hundred years ago, whose technique of cultural imperialism was to bombard Blacks with lectures about their "backwardness". Like Dlamini, Nhlapo suggests that the first step is to strive to deepen one's understanding of African culture in order to appreciate what was good in it, so as to isolate what has perverted it. ${ }^{77} \mathrm{He}$ suggests that the vital step towards the achievement of the envisioned version of African law is to separate the colonial/apartheid distortions from the non-racial and democratic norms of "living" African culture that harmonize with the Constitution. ${ }^{78}$ This is important because the legitimacy of the post-apartheid legal system in South Africa depends on the incorporation of the African experience, although it is viewed as controversial in the context of the history of South Africa.

The difference between these scholars and those discussed earlier, such as Keveey, English and Kroeze, is the reliance on the part of the latter group on the discredited "official" version of African law as ostensibly protecting culture $^{79}$ This is because the "official" version developed through the connivance of colonial authorities and African male elders, to invent a distorted tradition in which the latter gained exaggerated control over women and children under colonialism/apartheid. ${ }^{80}$ This revelation exposes the colonial origins of patriarchy in African law, and belies Keveey's thesis of an inherent disharmony between African culture and human rights. It further illustrates the danger of relying on the distorted version in the formulating a critique of African philosophy. ${ }^{8}$

In Nhlapo's diagnosis of the problem, the culture of individualism in which human-rights lessons are presented, is for many Africans reminiscent of "Westernization", which historically lacks respect for the African viewpoint. ${ }^{82}$ In contrast to Keveey's campaign for the discarding of African jurisprudence, Nhlapo insists that African law's support for the human-rights project is

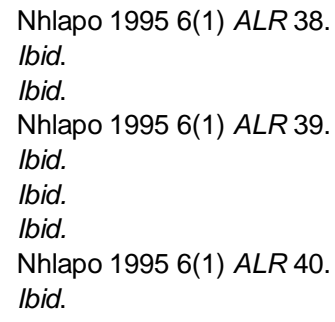


possible, especially if enlisted after convincing the majority of the role of the indigenous value system in influencing South Africa's constitutional norms. For Nhlapo, a good strategy for an acceptable concept of human rights would entail reassuring people that the title they hold in their rights is an entitlement, not a privilege that was enjoyed on sufferance. ${ }^{83}$ Such a reassurance imbues people with a vision of a South Africa that does not exploit individuals and groups for the benefit of a particular segment of society. ${ }^{84}$ Nhlapo emphasizes the Constitution's wisdom in positioning African law on par with the general law, whilst guaranteeing the right to culture and subjecting both systems to the Bill of Rights. ${ }^{85} \mathrm{He}$ then formulates his own understanding of the tension between the two legal cultures in South Africa as follows:

"The [relationships] that have ethnicity and/or culture at their centre are the ones which suffer most from the legacy of the past. African customary law is doubly vulnerable. The imperatives of transformation require that this law not only renegotiate its own content, but also the "political" relationship between itself and the rest of the legal system. This has to be done against the background of a dominant legal system and a dominant culture whose relationship with African culture has not in the past been very positive".

Nhlapo characterizes the tension that persists between the Western notion of retributive justice, and the traditional African concept of restorative justice, as the conflict between the classical "Western" approach, where the task of the Court is to adjudicate and punish; and those African notions reflecting values of reconciliation, restoration, and compromise. ${ }^{87}$ He then notes that the value of restorative justice is deeply embedded in African thinking, and that its incorporation into the mainstream would lead to an improved administration of justice. ${ }^{88}$

Nhlapo further suggests that this could be achieved by regularizing, strengthening, and enhancing the judicial function of the institution of traditional leadership, because African traditional methods of dispute resolution have always involved a strong restorative element. ${ }^{89}$ By emphasizing the value of mainstreaming African thinking and the benefits of restorative justice, this would contribute to the legal system.

Nhlapo's views challenge both the Afro-pessimistic campaign by Keveey, and English's nihilistic approach to African history. He sees no disharmony between African culture and the Constitution, but acknowledges the historical tension between the Western and African cultures. He develops what he calls the "paradigm of argument", to demonstrate the uniqueness of

B3 Nhlapo 1995 6(1) ALR 41.

84 Ibid.

85 Nhlapo "The Judicial Function of Traditional Leaders: A Contribution to Restorative Justice?" 14-17 March 2005 Paper presented at the Conference of the Association of Law Reform Agencies of Eastern and Southern Africa (ALRAESA) 2.

86 Nhlapo 14-17 March 2005 Paper presented at the Conference of the Association of Law Reform Agencies of Eastern and Southern Africa (ALRAESA) 3.

87 lbid.

88 Ibid.

89 Nhlapo 14-17 March 2005 Paper presented at the Conference of the Association of Law Reform Agencies of Eastern and Southern Africa (ALRAESA) 4. 
African thinking in the conduct of indigenous judicial proceedings. ${ }^{90}$

Lehnert's entry point is that the constitutional requirement that the courts must develop African law in line with the Bill of Rights erodes the Constitution's own cultural imperative.$^{91}$ Nevertheless he believes that the transformation of African law in South Africa is possible, if the arrangement of the constitutional provisions and the norms that inform their application are studied carefully. According to Lehnert, harmony in the humanrights/African culture dilemma depends on maintaining a proper balance between the constitutional provisions that oblige the courts to apply African law in line with human rights, on the one hand, ${ }^{92}$ with those that demand respect for culture, on the other. ${ }^{93}$

Lehnert finds a considerable convergence between human rights and the "living" law, and regrets that the courts have at times hidden behind the common law or statutory law, when the "living" law, suitably adjusted, could have resolved the matter. ${ }^{94}$ For Lehnert, when African law is offensive to the Bill of Rights, the development of "living" law is preferable to the options of applying common law or striking African law down. He concludes that the pedigree of African law as the culture of Black South Africans, resolves the question of which of the two versions is recognized by the Constitution in favour of "living" law. For him the "living" law is the version of African law that the Constitution recognizes, and which must conform to the Bill of Rights and constitutionally compliant legislation in order to achieve the envisioned transformation.

Bennett, ${ }^{95}$ Himonga and Bosch, ${ }^{96}$ Pieterse,${ }^{97}$ and Juma ${ }^{98}$ agree with Lehnert that on a proper reading of the constitutional structure, as analysed in the context of the history of African law and the politics of its recognition, the African law of post-apartheid South Africa, is the "living" version. With

90 To illustrate this Nhlapo, 14-17 March 2005 Paper presented at the Conference of the Association of Law Reform Agencies of Eastern and Southern Africa (ALRAESA) 6 says: "At its most fundamental, the rule-centred paradigm is grounded in a conception of social life as rule-governed and of normal behaviour as the product of compliance with established normative concepts. Consequently, [a] dispute acquires a pathological character; it signals deviance, a malfunction that the control institutions of a society are essentially designed to put right. Associated with this view of order is the contingent assumption, which goes a long way back in political theory that societies do not cohere effectively in the absence of centralised authorities, which formulate rules and ensure conformity with them."

91 Lehnert 200521 SAJHR 241.

$92 \mathrm{~S} 211$ (3) of the Constitution.

$93 \mathrm{~S} 30$ and 31 of the Constitution.

94 Lehnert 200521 SAJHR 262.

95 Bennett 2009 LVII(1) The American Journal of Comparative Law 7 writes: "Accordingly, s 30 and 31 of the Final Constitution of 1996 gave all persons a right to participate in the cultures of their choice and, because customary law was closely identified with an African cultural tradition, the courts accepted that those claiming application of customary law could base their demands on the right to culture".

96 Himonga and Bosch 2000117 SALJ 328 write: "Denying that law can exist outside the state-generated law is tantamount to denying that there is a right to culture".

97 Pieterse 2000 De Jure 45 writes: "[T] he written rules of customary law should as far as possible be reconciled with actual cultural practice".

98 Juma 2007 21(1) Speculum Juris 110 writes: "[T] he concept of living law ... places [African law] in a more accommodating and evolving system of societal organisation that we see in African communities today". 
regard to the judicial development of African law, Lehnert, ${ }^{99}$ Himonga and Bosch, ${ }^{100}$ Van Rensburg, ${ }^{101}$ Bonthuys, ${ }^{102}$ and Van Niekerk ${ }^{103}$ express a concern arising from the fact that the courts are obliged to apply "living" African law, whilst they are constitutionally obliged to develop it in line with the Bill of Rights. For these scholars this is the source of the tension between the two.

Van Niekerk seeks to resolve this dilemma by adding that "the adaptation of indigenous laws should not be in accordance only with the Bill of Rights as an instrument of entrenching Western values; it should rather also be in harmony with its own underlying postulates". ${ }^{104}$ This view is supported by Bronstein who emphasizes the importance of vigilance against the imposition of Western values in the transformation of African law. ${ }^{105}$ In support of this view Pieterse would also like to see South Africa's constitutional institutions incorporating as much African law and its values as are not in conflict with Constitution, so as to demonstrate that the basic values underpinning the Constitution are not inherently in conflict with African law norms, and that they are in fact amenable to legislative and judicial manipulation in influencing patterns of behaviour that are sensitive to human rights. ${ }^{106}$

Himonga and Bosch, and Pieterse, are agreed that the Bill of Rights does not necessarily mandate the constitutional institutions to abandon African law in favour of the common law. In particular Pieterse insists that the tension between certain African cultural practices and the Bill of Rights can gradually be overcome by a judicial extension of transformative influences through an innovative development of African law, in terms of section 39(2) of the Constitution. ${ }^{107}$ In endorsing this view Himonga and Bosch caution South Africans to remember that their constitutional institutions are struggling to accord equality to the two systems because of the history of depriving African law of the legal status of law of the land under apartheid. The latter scholars attribute the difficulties that inhibit these institutions from achieving the envisioned post-apartheid legal system to the culture of using the repugnancy proviso ${ }^{168}$ to recreate African law in the image of the Western-oriented common law. ${ }^{109}$

99 Lehnert 200521 SAJHR 251.

100 Himonga and Bosch 2000117 SALJ 316.

101 Van Rensburg "The Judiciary and its Constitutional Mandate to Develop and Apply Customary Law - Mthembu v Letsela revisited' 200122 Obiter 216227.

102 Bonthuys "The South African Bill of Rights and the Development of Family Law" 2002119 SALJ 748757.

103 Van Niekerk "Indigenous Law and the Constitutional Right to Equal Protection and Benefit of the Law" in De Villiers (ed) The Rights of Indigenous People: A Quest for Coexistence 1997207229

104 Ibid.

105 Bronstein "Reconceptualizing the Customary Law Debate in South Africa" 198814 SAJHR 388 402-404.

106 Pieterse 2000 De Jure 47.

107 Pieterse "It's a Black Thing: Upholding Culture and Customary Law in a Society Founded on Non-racialism" 200117 SAJHR 364392.

108 S 1(1) Act 45 of 1988 reads in part: "indigenous law shall not be repugnant to the principles of public policy and natural justice".

109 Himonga and Bosch 2000117 SALJ 309. 
Expressing his considerable faith in the compatibility of African law and human rights, Juma warns that the relationship between the two should be properly handled. He believes that the ideological framework, on which the South African Bill of Rights is based, differs fundamentally from that on which the erstwhile repugnancy clause was founded, and has the potential to contribute to the realization of the envisioned African law. This is because the "momentums for change that reside within the African traditional structures make them suitable as agents of societal transformation, and not inhibitors of such transformation".

Juma, therefore, agrees with the majority of scholars discussed above who believe in the transformability of African law to suit a human-rights environment. In his evaluation of the opinions that are sceptical of African law, Juma concludes that such sceptics also desire to see African law operating in a human-rights environment in the end. All that needs to be done is to find a way of applying African law in the context of international human rights premised on individual rights and freedoms. ${ }^{11}$

\section{THE VIEW THAT THE COMMUNAL NATURE OF AFRICAN CULTURE MAKES IT AMENABLE TO THE VALUES OF THE CONSTITUTION}

The communal nature of African culture is the thread that runs through the works of Dlamini, Nhlapo, Mahao and Himonga and Bosch, as discussed in the above section. These views present this feature of African traditions as endowed with attributes which are amenable to the development of a progressive justice system. This is the basis for these scholars' collective call for the revival of Africa's communitarian traditions which they believe can contribute to the emergence of the version of the African law that the Constitution envisions.

Elechi ${ }^{112}$ and Ade Ajayi ${ }^{113}$ also rely on similar features of the Africa culture in their appraisal of the sentiments expressed by Nhlapo regarding the grip of indigenous values on traditional institutions of social control in Africa, which have endured despite Africa's entanglement in the coloniallysponsored justice system. Their view is that the resilience of the principles of the African indigenous justice system lies in the fact that it is communitybased; human-centred, and employs restorative and transformative methods.

Ade Ajayi adds that African culture is an indispensable medium for resolving issues in Africa. Like Dlamini, Nhlapo, Mahao and Himonga and Bosch, Ade Ajayi believes that the history of the African tradition must be studied seriously in order to excavate the real norms and values that may

\footnotetext{
10 Juma 2007 21(1) Speculum Juris 91.

11 Juma 2007 21(1) Speculum Juris 90.

112 Elechi "Human Rights and the African Indigenous Justice System" 8-12 August 2004 Paper presented at the $18^{\text {th }}$ International Conference of the International Society for the Reform of Criminal Law, Montreal, Quebec, Canada.

113 Ade Ajayi "Social Justice in Traditional African Societies" in Falola (ed) Tradition and Change in Africa (2002) 3.
} 
have been buried through the injustices of the past. ${ }^{114}$ In contrast to the pessimism of English, Keveey and Kroeze, Ade Ajayi cherishes the value of the ancient African jurisprudence and its significance in shaping the profoundly altered modern African environment.

To Ade Ajayi, present-day Nigeria is an example of a modern African state's inability to completely jettison African culture, even in the face of the temptation to do so, from the dominant Western institutions. He sees this as evidence of the durability of the underlying indigenous normative system. For him African culture hinges on three basic concepts, namely, humanism, community and participation, which are the reason why modern perceptions of social justice continue to be influenced by their traditional version. ${ }^{1}$

In a way that is comparable with Dlamini's conception of ubuntu, ${ }^{117}$ Ade Ajayi defines "humanism" as the responsibility of accepting all human beings as creatures of God who possess dignity and social and moral worth that demand respect. This respect extends to relatives, friends, strangers, and enemies, and includes the relations between rulers and the ruled, urban and rural dwellers, farmers and cattle rearers, rich and poor, masters and slaves, elders and the youth, and men and women alike. As a feature of good governance, humanism curbs corruption by simultaneously limiting the temptation to accumulate, and facilitating access to land and other resources. This blocks the emergence of social classes by investing wealth in the people and not in large estates. ${ }^{118}$

Ade Ajayi presents the community as the heart of African society, in which the value of the individual lies in the context of the collective. The latter is the centre around which all activities are organized. Together with humanism and community, Ade Ajayi adds participation in community activities, engendered by the closeness of the relations and interdependence amongst community members, as the third concept that characterized traditional African society. ${ }^{119}$ This feature entails that the individual's actions, including accidental ones, could affect the well-being of the whole community. This made participation in the affairs of the community both a right and a civic

114 Ade Ajayi in Falola (ed) Tradition and Change in Africa 3.

115 Ibid. See also Abiodun "Towards an African Concept of Law" 2007 African Journal of Legal Theory $71,72$.

116 Ade Ajayi in Falola (ed) Tradition and Change in Africa 4.

117 Dlamini 2002 1(1) Speculum Juris 42.

118 Ibid. See also Allott "What is to be done with African Customary Law? The Experience of Problems and Reforms in Anglophone Africa from 1950" 1984 28(1-2) JAL 56 59-60, where he agrees that serious changes occurred in the African lifeworld. He writes: "There was, however, a very substantial modification of the customary laws in the years of colonia rule. This could be attributed to changes initiated by the people themselves in their patterns of family life, in their forms of economic activity, in their notions about property rights responding to the introduction into Africa of Western systems of education, religious principles, economic activities and property holding. The possibility of cultivating crops for the market rather than for consumption led to enormous changes in African land tenure. It was of the very nature of customary law that these changes could be made without formal legislation, by the people themselves who were subject to the law - the people as lawmakers. It was similarly of the essence of customary law that the customary courts should reflect these changes in popular practice and attitude through their decisions, which they duly did."

119 Ade Ajayi in Falola (ed) Tradition and Change in Africa 4. 
duty, as it went far beyond the periodical election of leaders to public office.

\section{THE VIEW THAT CERTAIN RULES, PRINCIPLES AND CONCEPTS OF TRADITIONAL AFRICAN LAW ARE CENTRAL TO THE RESOLUTION OF SOCIO-LEGAL DISPUTES}

Koyana, ${ }^{120}$ Mailula, ${ }^{121}$ and Ntlama ${ }^{122}$ identify certain traditional institutions as vital for resolving customary-law disputes and decry their sidelining in statutory and judicial decision-making. In particular Koyana resents the resilience of the discredited repugnancy jurisprudence in South African law as a retrogressive step. ${ }^{123}$ He dismisses the overlooking of tried and tested methods of resolving marital dispute, and blames this on the uncritical introduction of the Western-oriented concept of irretrievable breakdown of marriage as a ground of divorce. According to Koyana this is the result of failure to heed the dissenting voices that protested against the jettisoning of African law in the name of justice and equity.

Among such protesters, Koyana counts a member of the Native Appeal Court who once deplored the use of foreign ethical ideas to judge the lobolo institution. ${ }^{124}$ This criticism was evoked by the enthusiasm to substitute common-law moral values for those of customary law in the name of acting in the best interests of the Africans. As an example hereof he quotes Gidja $v$ Yingwane in the following terms:

"It is not always in the interests of the natives themselves to give the court's sanction to all their present day alleged customs. It is one of the functions of this court to interpret native law and custom in conformity with civilised ideas of what is fair and just."

Koyana's disillusionment springs from the legislative neglect of the important traditional remedies of ukutheleka ${ }^{126}$ and ukuphuthuma ${ }^{127}$ which are so relevant to the dissolution of customary marriages. ${ }^{128}$ Ukutheleka is an indigenous wife-protection method, in terms of which the wife's maiden relatives asserted their right to protect her against her abusive husband until

120 Koyana "The Resilience of the Repugnancy Clause in the Customary Law of South Africa" in Osode and Glover (eds) Law and Transformative Justice in Post-apartheid South Africa (2010) 491.

121 Mailula "Abdication of Judicial Responsibility, Cultural Self-determination and the Development of Customary Law: Lessons from Shilubana" 200823 SAPR /PL 215.

122 Ntlama “'Equality' Misplaced in the Development of Customary Law of Succession: Lessons from Shilubana v Nwamitwa 2009 (2) SA 66 (CC)" 2009 20(2) Stell LR 333.

$123 \mathrm{~S} 1(1)$ of the Law of Evidence Amendment Act, 45 of 1988 in part reads: "[i]ndigenous law shall not be opposed to the principles of public policy and natural justice: Provided further that it shall not be lawful for any Court to declare that the custom of lobola or bogadi or other similar custom is repugnant to such principles".

124 Gomani v Baqwa NAC Records (1912-1917) 71.

1251944 NAC (N\&T) 4.

126 Koyana in Osode and Glover Law and Transformative Justice in Post-apartheid South Africa 495.

127 Ibid. See also Bekker Seymour's Customary Law in Southern Africa 181-182.

128 Koyana in Osode and Glover Law and Transformative Justice in Post-apartheid South Africa 501-502. 
he had fully accounted for ill-treating her. In terms of this right the wife's maiden family would keep her until the husband assured them that he would desist from further abuse and has undertaken to treat her with dignity in future. The husband makes such assurances and undertakings during an expedition to his wife's maiden home, known as ukuphuthuma, during her ukutheleka sojourn at her family home, to negotiate her return. ${ }^{129}$

During the ukuphuthuma negotiations, the husband and his family must account for the abusive conduct of the husband to the wife's family. He must apologise profusely and unreservedly to the wife and her family with a view to bringing the ukutheleka to an end. More importantly, the husband must pay the fine that is imposed by his wife's family as part of the deal for their accepting his apology and he must commit himself to adhering to the terms and conditions of his wife's return to him.

Koyana concludes that in the absence of these traditional remedies, "the impact of the new provision prescribing the common-law ground of irretrievable breakdown, as the only ground for divorce in customary marriages, on customary law and the law relating to marriage is simply devastating". Hence Koyana feels depressed by the negation of African law by the judiciary, including the Constitutional Court in cases such as Bhe $v$ Mgistrate Khayelitsha, where a common-law solution was imposed on a matter that is regulated by customary law. ${ }^{130}$

Mailula supports the view that the courts should apply traditional methods of dispute resolution, and expresses his disenchantment with the Constitutional Court's abdication of this duty in the Shilubana case. ${ }^{131}$ As a solution he suggests a balancing of constitutional rights with indigenous values in a way that recognizes the primacy of the cultural imperative over individual autonomy. In that way the preservation of the primogeniture rule as a method of succession in traditional leadership can be justified. ${ }^{132}$

Ntlama is another staunch supporter of the adhering to the indigenous methods of dispute resolution. In agreeing with Mailula she fingers the overemphasis on the principle of equality in disproportion to customary-law norm of adjudication, and decries the resultant undermining of the ability of African culture to develop its own jurisprudence, based on non-discrimination. ${ }^{133}$ Bronstein expresses similar views, and rejects the idea that African women must necessarily resort to equality jurisprudence each time they fight for their African law-based rights. She insists that African law is capable of resolving its intra-cultural disputes without the need to drag in the Constitution as a club to quell a cultural quarrel. ${ }^{134}$ Lehnert sees this as a new threat from the Constitution to the standard of highest principles and values of society. ${ }^{135}$ He blames it for having instilled fear in traditional leaders during the negotiations; thus inducing them to seek, albeit without

129 Bekker Seymour's Customary Law in Southern Africa 181-189.

130 Bhe v Mgistrate Khayelitsha supra para 117-136.

131 Mailula 200823 SAPR /PL 215235.

132 Mailula 200823 SAPR /PL 235.

133 Ntlama 2009 20(2) Stell LR 355-356.

134 Bronstein 198814 SAJHR 402-404.

135 Lehnert 200521 SAJHR 243. See also Ebo "Indigenous Law and Justice: Some Major Concepts and Practices 197976 African Law and Legal Theory 139144. 
success, to exempt African law from the inevitable review process that awaited the whole of the South African legal system under the Bill of Rights.

In Koyana's observation the main distinguishing feature between African law and common law clearly shows that one cannot just substitute the one system for the other without causing major distortions. He says that the fact the former has more communal, concrete, transparent, as well as religious or sacred characteristics, than the latter is a clear indication that the two are rooted in different moral substrata. ${ }^{136}$ Each system has distinctive background rules and regulations for enforcing order, which makes it inappropriate to judge one by using the other's value system. ${ }^{137}$ Koyana traces the history of non-recognition of African law to the British colonial policy of civilization and Christianity, driven by Governor Grey who denied that communalism and individualism are two distinctive characteristics, calling for different approaches. ${ }^{138}$

In a way that is reminiscent of Thomas and Tladi's pessimism about the future of customary law under the Constitution, Koyana notes a worrying point of similarity between the status of African law under apartheid and under the Bill of Rights, where African law was again subjected to the latter's Westernizing influence. ${ }^{139}$ Hence Koyana feels depressed by the negation of African law by the Constitutional Court in cases, such as Bhe $v$ Mgistrate Khayelitsha, which substituted the common law of succession for African law.

\section{$9 \quad$ CONCLUSION}

The balance of the debates that came to the fore in this article shows that an unrestrained Westernization of the African lifeworld is the cause of the dilemma faced by many Africans in their efforts to rescue their knowledge system from the brink of oblivion. This is so because the African culture is a distinct thought system that stands on its own epistemological underpinnings that should not be viewed through Western metaphysical lenses. Hence the majority of the scholars herein favour the conclusion that African values require the individual to fulfil his/her obligations in the community in return for social validation, protection, membership and security.

This view is also in line with Ngcobo J's proposal for a "degenderized" primogeniture principle that can advance the realization of a non-sexist and democratic society, as envisaged in section 1 of the Constitution, because African culture is founded on the premise that in each and every family there

136 Koyana in Osode and Glover Law and Transformative Justice in Post-apartheid South Africa 491.

137 Koyana in Osode and Glover Law and Transformative Justice in Post-apartheid South Africa 492.

138 Bennett Application of Customary Law in South Africa (1985) 41 writes: "The White opinion of customary law was a low one and it was argued that if everyone in the Colony were compelled to abide by the laws of the more civilised section of society those of the lower station would be forced to reach the higher standards".

139 Koyana in Osode and Glover Law and Transformative Justice in Post-apartheid South Africa 495.

140 Bhe v Mgistrate Khayelitsha supra par 117-136. 
is some senior person who can be held liable to take responsibility for the support of vulnerable members, regardless of his or her sex. ${ }^{141}$ For this reason, the cultural orientation of the indigenous authors, and their personal experiences in traditional environments, commend them as indispensable aids for reconceptualizing African law under the Constitution. This is particularly so as their contexts are located within a world view that is governed by indigenous jural postulates.

The usefulness of the contributions written in indigenous languages also belies the almost axiomatic emphasis on the absence of original materials on customary law. Instead such materials reveal the workings of the:

"African indigenous economic, social and political institutions that function as channels for conflict resolution as the basis for the system's social solidarity, humane emphasis, popularity and legitimacy".

The indigenous conception of law and justice articulated by indigenous authors, is in the best position for formulating a post-imperial notion of constitutionalism on which the transformation of our law depends.

As Jolobe points out, the use of technology to advance cooperation between men and women enriches the quality of family life in rural areas, and influences the development of community views on gender roles in society. ${ }^{143}$ Herein lies the value of interdependence between men and women in African tradition, and how the intersection between their roles serves to eliminate the patriarchal traditions over time. ${ }^{144}$ Hence the reduction of gender stereotypes and the advancement of a convergence of gender roles contribute to the lowering of the tension between customary law and the Constitution.

Thus construed, the African tradition of using manhood as an institution for promoting justice rather than being a symbol of patriarchy, helps to develop an appreciation of indigenous values as contributing to the growth of human rights among both urban and rural South Africans. Thus a positive view of African culture on the interaction between men and women generates an interpretation of an egalitarian customary law that reduces the temptation to substitute foreign ideas in the formulation of judicial and legislative decisions by State institutions. Hence the emergence of the growing optimism as reflected in the number of African law scholars who see the synergy between customary law and the Constitution. Ironically the very recognition of African law's distinctiveness as an original thought system also arouses scepticism in the minority of scholars who believe in the universality of the Western value system and its hegemony. The shape and content of post-apartheid African law is the product of the distillation of these discourses with indigenous, Western and human-rights elements, mingled together to form a distinct component of the South African legal system.

\footnotetext{
141 Bhe v Mgistrate Khayelitsha supra par 139.

142 Nhlapo 14-17 March 2005 Paper presented at the Conference of the Association of Law Reform Agencies of Eastern and Southern Africa (ALRAESA) 3.

143 Jolobe in Bennie Imibengo 225-226.

144 Setiloane The Image of God Among the Sotho-Tswana 40.
} 